\title{
Two new species of Justicia (Acanthaceae) from northern Thailand
}

\author{
Kanokorn Rueangsawang ${ }^{1}$, Pranom Chantaranothai ${ }^{2}$ \& David A. Simpson ${ }^{3}$ (D)
}

Summary. Two new species, Justicia flavescens and J. vasculosoides are described and illustrated from northern Thailand. Both species have restricted distributions. The conservation status of each species is assessed.

Key Words. Asia, conservation status, morphology, pollen, taxonomy.

\section{Introduction}

Justicia L. is a large pantropical genus of Acanthaceae with c. 600 species (Graham 1988; Mabberley 2008).

The genus is easily recognised by its zygomorphic, bilabiate corolla having a rugula (a stylar furrow which runs along the centre of the upper lip) (Kiel et al. 2017), bithecous anthers with appendages or a white tail (rarely absent), 2-porate pollen grains that are 2 3-colporate with aperture areas or 3-colporate with six pseudocolpi (Rueangsawang et al. 2013) and four seeds held on retinacula. A recent analysis of the nrITS and the cpDNA sequence data by Kiel et al. (2017) suggests that Justicia s.l. is highly paraphyletic, with New World and Old World clades, both of which have morphologically distinct lineages nested within them. In particular, it revealed that Justicia from the Old World is sister to subtribe Diclipterinae (Dicliptera (=Peristrophe) and Hypoestes). Members of Diclipterinae lack the rugula that is usually present in justicioid lineages. Keil et al.'s work also has implications for the infrageneric classification of Graham (1988), as several of her sections prove to be polyphyletic.

The first record of Justicia from Thailand was the newly described J. bicalcarata Craib (Craib 1912). Since then 19 new species have been found in the country (Imlay 1939). Further studies of the genus in Thailand were undertaken by Ridley (1922), Imlay (1938), Hansen $(1985,1987,1989)$ and the Forest Herbarium (2014). In a recent treatment for Thailand (Rueangsawang 2012), 50 taxa (48 species and two varieties) were delimited. During recent fieldwork in northern Thailand, specimens were collected that did not match with any of the known taxa of Justicia. After detailed examination, it was concluded that they represent species new to science and are described below. A key that includes the new species will be presented in the forthcoming Flora of Thailand account of the genus (Rueangsawang et al. in prep.).

\section{Materials \& Methods}

Extensive fieldwork was undertaken in Tak, Kamphaeng Phet and Sukhothai provinces, northern Thailand in 2014 by the first author. Specimens collected during the fieldwork were pressed, dried and examined both directly and under a binocular microscope. Material in AAU, BK, BKF, BM, C, CMU, E, K, KKU, L, P, QBG and SING was also examined and compared to other Asian taxa in order to determine whether the specimens collected during fieldwork represented new taxa. Data were assembled into a Microsoft ${ }^{\circledR}$ Excel $^{\mathrm{TM}}$ spreadsheet, from which the species descriptions were written. For the conservation assessments the IUCN Red List categories and criteria (IUCN 2012) were applied; extent of occurrence (EOO) and area of occupancy (AOO) were measured using Geocat software (http://geocat.kew.org/; Bachman et al. 2011). All specimens seen are indicated by '!'.

\section{Taxonomy}

Justicia flavescens Rueangs. $\mathcal{E}$ Chantar. sp. nov. Type: Thailand, Sukhothai province, Si Satchanalai National Park, Tat Dao waterfall, 10 Nov. 2016, K. Rueangsawang 308 (holotype $\mathrm{BKF}$ !; isotypes $\mathrm{K}$ !, KKU!).

http:/ /www.ipni.org/urn:lsid:ipni.org:names:60479210-2

Subshrubs up to $1.5 \mathrm{~m}$ tall. Stems woody, erect, quadrangular, with longitudinal green lines, pubescent when young, swollen at nodes. Leaves chartaceous, upper surface variegated when young, $14-21 \times 3-8 \mathrm{~cm}$, lanceolate or rarely ovate, base attenuate, margin entire, apex acuminate

\footnotetext{
Accepted for publication 17 July 2019. Published online 9 September 2019

1 Department of Biology, Faculty of Science, Ramkhamhaeng University, Bangkapi, Bangkok, 10240, Thailand.

2 Department of Biology \& Centre of Excellence on Biodiversity (BDC), Faculty of Science, Khon Kaen University, Khon Kaen, 40002 , Thailand

3 Royal Botanic Gardens, Kew, Richmond, Surrey, TW9 3AB, UK. e-mail: d.simpson@kew.org
} 
or caudate; cystoliths linear, conspicuous on lower surface; minutely pubescent along midrib; lower surface puberulent; lateral veins in $6-10$ pairs; petioles $1.5-5 \mathrm{~cm}$ long, grooved above, pubescent. Inflorescences comprising terminal spikes, $8-15 \mathrm{~cm}$ long, unbranched or with a single branch; rachis pubescent; peduncles c. $1 \mathrm{~cm}$ long, pubescent. Flowers sessile, opposite at each inflorescence node, each flower subtended by 1 bract and 2 bracteoles; bract 4-ranked, imbricate, pale green, upper bract ovate or lanceolate, $8-13 \times 4-6 \mathrm{~mm}$, base obtuse or cuneate, margin ciliate, apex acute or acuminate, surfaces pubescent, lower bracts foliaceous and narrowly ovate, $20-25 \times 3$ - $4 \mathrm{~mm}$, base cuneate, margin entire, apex caudate, glabrous, bracts longer than calyx; bracteoles $3-5 \times$ c. 1 $\mathrm{mm}$, lanceolate, margin ciliate, apex acuminate, surfaces minutely pubescent to glabrous, shorter than calyx. Calyx deeply 5-lobed, greenish, $4-6 \times 0.5-0.7 \mathrm{~mm}$, lobes linearlanceolate, apex acuminate, margin ciliate, sparsely pubescent outside, glabrous inside. Corolla yellowish, without markings on palate of lower lip, 18 - $20 \mathrm{~mm}$ long, finely pubescent outside; tube cylindrical, 13 - $15 \mathrm{~mm}$ long, slightly enlarged in throat; upper lip 5-7 mm long, broadly triangular, slightly hooded, not emarginate; lower lip 5-10 $\times 7-8 \mathrm{~mm}$, lateral lobes c. $1 \times 1-1.3 \mathrm{~mm}$, middle lobe c. $1 \times$ $1.5-2 \mathrm{~mm}$, three lobes spreading, palate with conspicuous venation. Stamens $4-5 \mathrm{~mm}$ long, glabrous, attached near upper part of corolla tube; filaments straight; anthers separate, 2-thecous, c. $1.5 \mathrm{~mm}$ long, subequal, lower theca 1 - $1.3 \mathrm{~mm}$ long, with tail c. $0.1 \mathrm{~mm}$ long, upper theca c. $1 \mathrm{~mm}$ long. Ovary ovoid, glabrous; style 13 - $20 \mathrm{~mm}$ long, filiform, strigulose in lower half; stigma with 2, minute, unequal lobes. Capsules $1.5-2 \mathrm{~cm}$ long, obovoid, apex acute, densely pubescent. Seeds $4,1.8 \times 2 \mathrm{~mm}$, suborbicular, dark brown, rugulose-tuberculate. Figs $1 \& 2$.

RECOGNITION. Justicia flavescens is morphologically similar to J. cochinchinensis Benoist in having flowers that are sessile and opposite at each inflorescence node, a long inflorescence and 4-ranked bracts, but can be distinguished by lanceolate or rarely ovate leaves (vs ovate throughout in J. cochinchinensis); bracts foliaceous towards base of inflorescence but rapidly narrowing to ovate or lanceolate upwards (vs not foliaceous towards base of inflorescence); pale green bract coloration (vs pale green with purple margin); yellowish corolla without markings on the lower lip (vs white to pale pink with reddish or purple markings on the lower lip) and corolla tube longer than the corolla lip (vs tube as long as corolla lip). A comparison between J. flavescens and J. cochinchinensis is presented in Table 1 .

DISTRIBUTION. Endemic to Thailand and only known from Si Satchanalai National Park (Map 1).

SPECIMENS EXAMINED: THAILAND. Sukhothai: Si Satchanalai National Park, Tat Dao waterfall, $17^{\circ} 33^{\prime} 16.4^{\prime \prime} \mathrm{N}, 9^{\circ} 29^{\prime} 00.8^{\prime \prime E}, 148 \mathrm{~m}$ alt., 18 Nov. 2014, M. Norsaengsri 1153 (QBG!); same locality, $17^{\circ} 33^{\prime} 17.6^{\prime \prime} \mathrm{N}, 99^{\circ} 28^{\prime} 54.3^{\prime \prime E}, 203 \mathrm{~m}$ alt., 10 Nov. 2016,
K. Rueangsawang 305 (holotype BKF!; isotypes K!, $\mathrm{KKU} !)$.

HABITAT. Along streams in sandy soil, in open bamboo forest; alt. 148 - 203 m. Associated with Adiantum philippense L., Barleria siamensis Craib, Eranthemum tetragonum A.Dietr. ex Nees, Lygodium polystachyum Wall. ex Moore and Thelypteris sp. etc.

CONSERVATION STATUS. This species is known only from the type locality which lies within in a protected area. It is rare and there appears to be only one small population along a nature trail in an area frequently visited by tourists. Therefore, it should be considered as Vulnerable [VU D2] according to the IUCN (2012) criteria.

PHENOLOGY. Flowering and fruiting between November - January.

ETYMOLOGY. The name of this species is derived from the Latin for yellowish. This refers to the colour of the corolla which is unusual in Justicia.

NOTE. Both Justicia flavescens and J. cochinchinensis have characteristics of Justicia sect. Vasica (sensu Graham 1988), such as simple spicate inflorescence with ovate bracts.

Justicia vasculosoides Rueangs. E Chantar. sp. nov. Type: Thailand, Tak province, Namtok Pha Charoen National Park, Pha Charoen waterfall, 15 Jan. 2014, K. Rueangsawang 285 (holotype BKF!; isotypes $\mathrm{K}$ !, KKU!).

http:/ /www.ipni.org/urn:lsid:ipni.org:names:77198949-1

Subshrubs up to $1 \mathrm{~m}$ tall. Stems woody, erect, quadrangular, with longitudinal dark lines, sparsely pubescent when young, swollen at nodes. Leaves chartaceous, upper surface variegated when young, $6-14 \times 3-6 \mathrm{~cm}$, ovate, base attenuate, margin entire, apex acuminate or sometimes caudate; cystoliths linear, conspicuous on both surfaces; minutely pubescent along midrib; lower surface glabrous; lateral veins in $7-9$ pairs; petioles $1-6 \mathrm{~cm}$ long, grooved above, minutely pubescent. Inflorescences terminal and in upper axils; spikes $2-6 \mathrm{~cm}$ long, unbranched or with up to 3 pairs of branches; rachis minutely pubescent; peduncles $1-3 \mathrm{~cm}$ long, sparsely pubescent or glabrous. Flowers sessile, opposite at each inflorescence node, each flower subtended by 1 bract and 2 bracteoles; bracts $3-7 \times$ 1 - $3 \mathrm{~mm}$, oblanceolate, base obtuse, margin ciliate or entire, apex acute, surfaces sparsely pubescent or glabrous, shorter than calyx; bracteoles $1-3.2 \times 1-1.2 \mathrm{~mm}$, lanceolate, margin ciliate, apex acute, surfaces pubescent to glabrous, shorter than calyx. Calyx deeply 5-lobed, greenish, $3.7-5 \times 0.7-1 \mathrm{~mm}$, lobes linear-lanceolate, apex acuminate, margin ciliate, pubescent with glandular hairs outside, glabrous inside. Corolla pink or white with pinkish markings on palate of lower lip, $14-17 \mathrm{~mm}$ long, finely pubescent outside; tube cylindrical, $5-8 \mathrm{~mm}$ long, slightly enlarged in throat; upper lip 6-8 mm long, broadly triangular, slightly hooded, not emarginate; lower lip $6-8 \times$ $5-9 \mathrm{~mm}$, lateral lobes $1-2 \times 2-2.5 \mathrm{~mm}$, middle lobe 


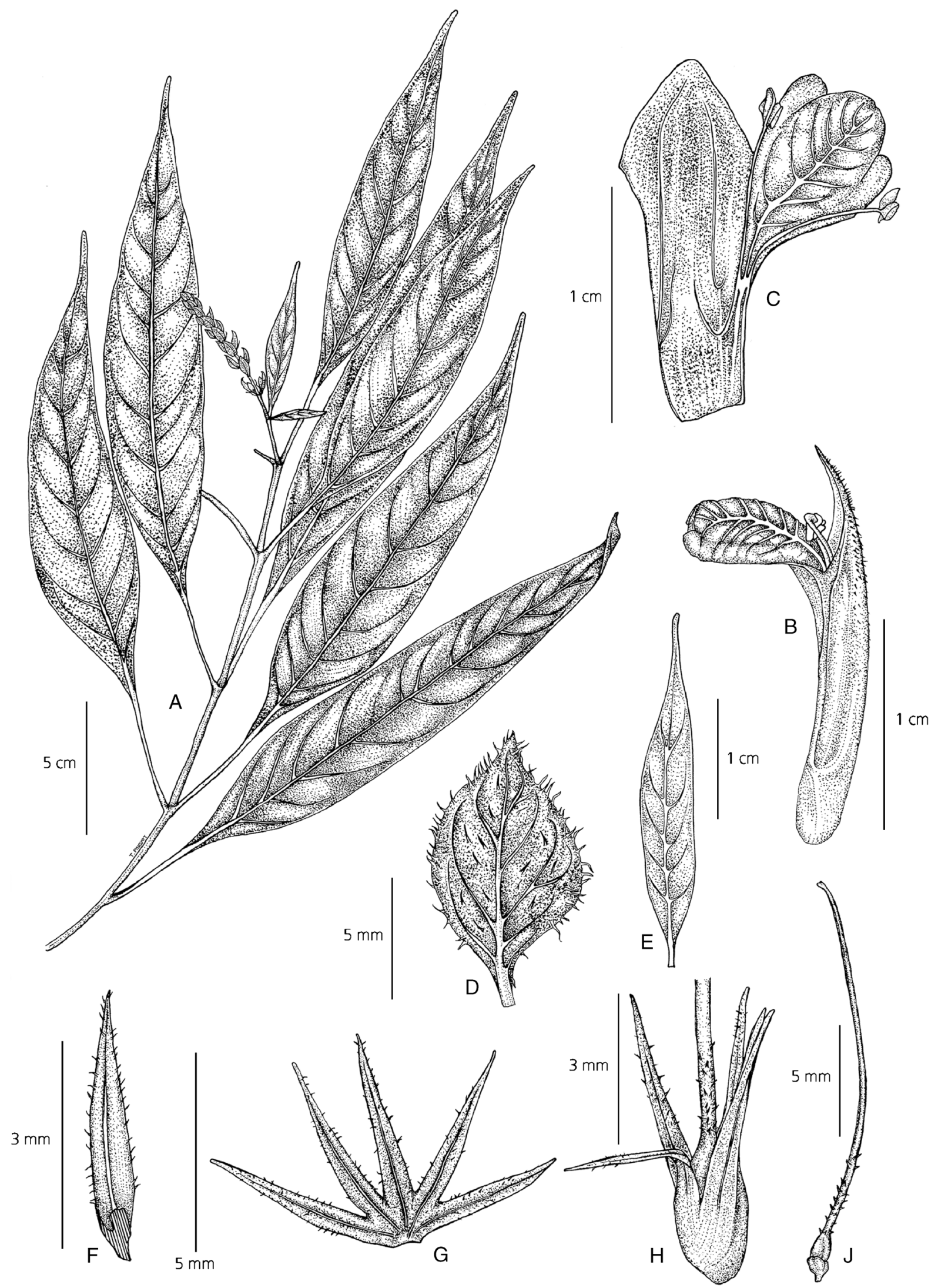

Fig. 1. Justicia flavescens A plant with inflorescence; B flower, lateral view; C dissected corolla, with stamens attached; D upper bract; E lower bract; F bracteole; G calyx; H calyx with ovary; J pistil. All from the type. DRAWN BY T. PINGYOT. 

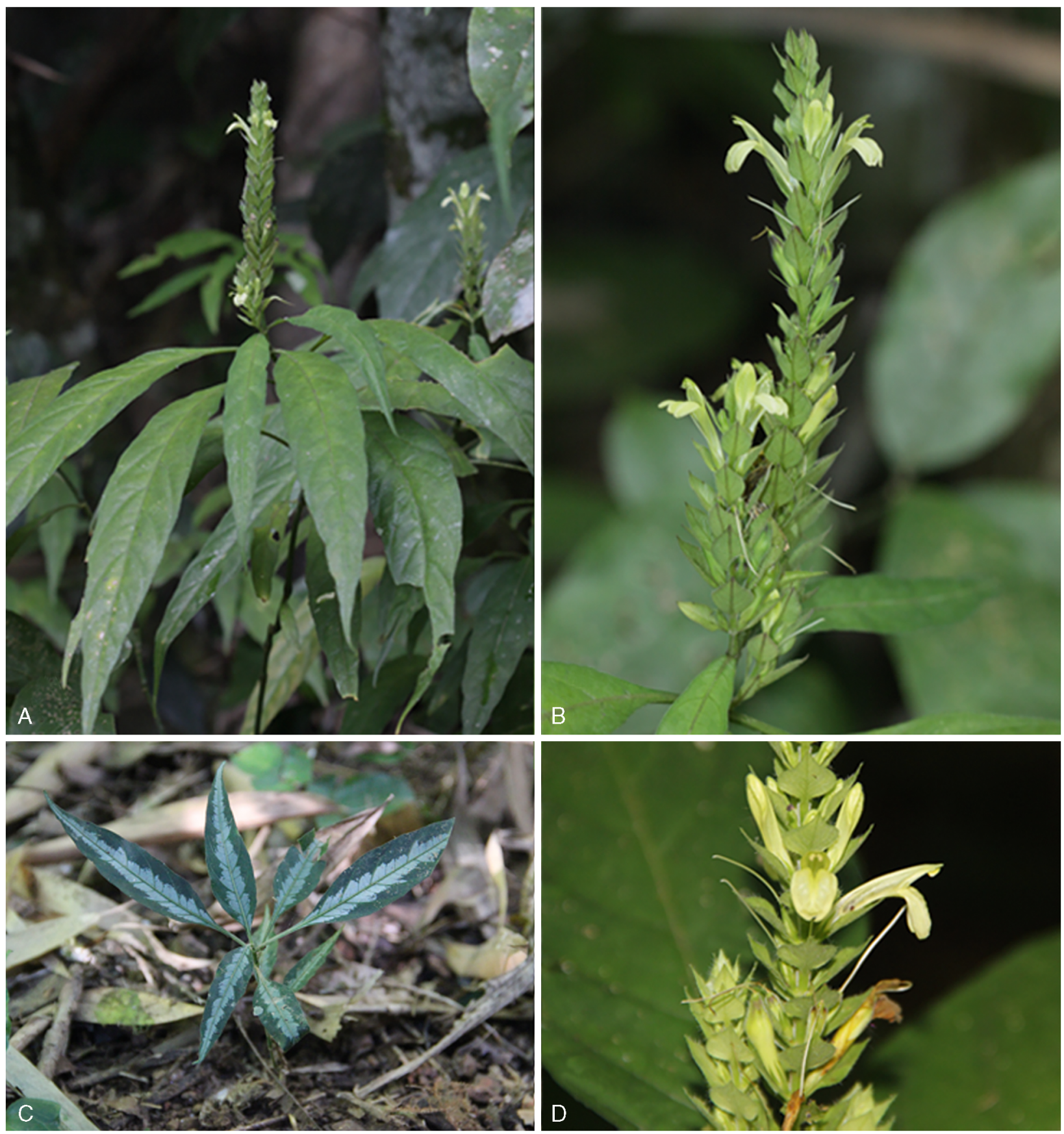

Fig. 2. Justicia flavescens A plant habit; B inflorescence; C variegated leaf surface when young; D flowers. PHOTOS: W. TANMING.

broader, $2-2.5 \times 2.5-2.8 \mathrm{~mm}$, the 3 lobes spreading, palate with conspicuous venation. Stamens $3-4 \mathrm{~mm}$ long, glabrous, attached near middle part of corolla tube; filaments straight; anthers separated, 2-thecous, c. $1.8 \mathrm{~mm}$ long, subequal, lower theca $1-1.3 \mathrm{~mm}$ long, with tail c. $0.1 \mathrm{~mm}$ long, upper theca c. $1 \mathrm{~mm}$ long. Ovary ovoid, glabrous; style 13-15 mm long, filiform, strigulose in lower half; stigma with 2, minute, unequal lobes. Capsules 1 $1.2 \mathrm{~cm}$ long, obovoid, apex acute, pubescent. Seeds 4, $2.6 \times$ $1.8 \mathrm{~mm}$, suborbicular, pale brown, rugulose-tuberculate. Figs 3 \& 4.
RECOGNITION. Justicia vasculosoides is morphologically similar to J. vasculosa (Wall. ex Nees) T.Anderson in having ovate leaves and a lax inflorescence with a single flower subtended by one bract and two bracteoles, but can be distinguished by the glabrous leaf surface with an acuminate or caudate apex (vs sparsely pubescent with an acute or rounded apex in J. vasculosa); inflorescence $2-6 \mathrm{~cm}$ long, glabrous or with minute pubescence (vs inflorescence $7-19 \mathrm{~cm}$ long with dense glandular hairs) and a pink or purple corolla tube (vs cream-coloured or white). A compar- 
Table 1. Comparison of selected characters between Justicia flavescens and J. cochinchinensis.

\begin{tabular}{|c|c|c|}
\hline Character & J. flavescens & J. cochinchinensis \\
\hline \multicolumn{3}{|l|}{ Leaf } \\
\hline texture & chartaceous & coriaceous \\
\hline shape & lanceolate, ovate & ovate \\
\hline apex & acuminate or caudate & acute or cuneate \\
\hline base & attenuate & attenuate or obtuse, oblique \\
\hline size $(\mathrm{cm})$ & $14-21 \times 3-8$ & $5.5-12 \times 3-8.5$ \\
\hline \multicolumn{3}{|l|}{ Bract } \\
\hline $\begin{array}{l}\text { arrangement } \\
\text { colour } \\
\text { size }(\mathrm{mm})\end{array}$ & $\begin{array}{l}\text { 4-ranked, imbricate, longer than calyx } \\
\text { pale green with ciliate margin } \\
8-13 \times 4-6\end{array}$ & $\begin{array}{l}\text { 4-ranked, imbricate, longer than the calyx } \\
\text { pale green with purple margin } \\
8-15 \times 6-10\end{array}$ \\
\hline \multicolumn{3}{|l|}{ Calyx } \\
\hline size $(\mathrm{mm})$ & $4-6 \times 0.3-0.5$ & $4-6 \times 0.9-1$ \\
\hline \multicolumn{3}{|l|}{ Corolla } \\
\hline colour & yellowish, without markings & $\begin{array}{l}\text { white to pale pink with reddish or purple } \\
\text { markings on palate of lower lip }\end{array}$ \\
\hline tube length (mm) & $13-15$ & $7-9.5$ \\
\hline \multicolumn{3}{|l|}{ Capsule } \\
\hline indumentum & densely pubescent & pubescent \\
\hline length $(\mathrm{cm})$ & $1.5-2$ & $0.8-1.2$ \\
\hline
\end{tabular}

ison between J. vasculosoides and J. vasculosa is presented in Table 2.

DISTRIBUTION. Northern Thailand (Map 1), near the Myanmar border and possibly occurring in Myanmar although no material from here has yet been collected.
SPECIMENS EXAMINED: THAILAND. Tak: Namtok Pha Charoen National Park, Pha Charoen waterfall, $16^{\circ} 30^{\prime} 07^{\prime \prime N}, 98^{\circ} 45^{\prime} 09^{\prime \prime E}, 600 \mathrm{~m}$ alt., 15 Jan. 2014, K. Rueangsawang 285 (holotype BKF!; isotypes $\mathrm{K}$ !, KKU!); Kamphaeng Phet: Chong Yen, Chong Yen Mae Wong National Park, 1602'22"N, 99 $14^{\circ} 00^{\prime \prime E}$,

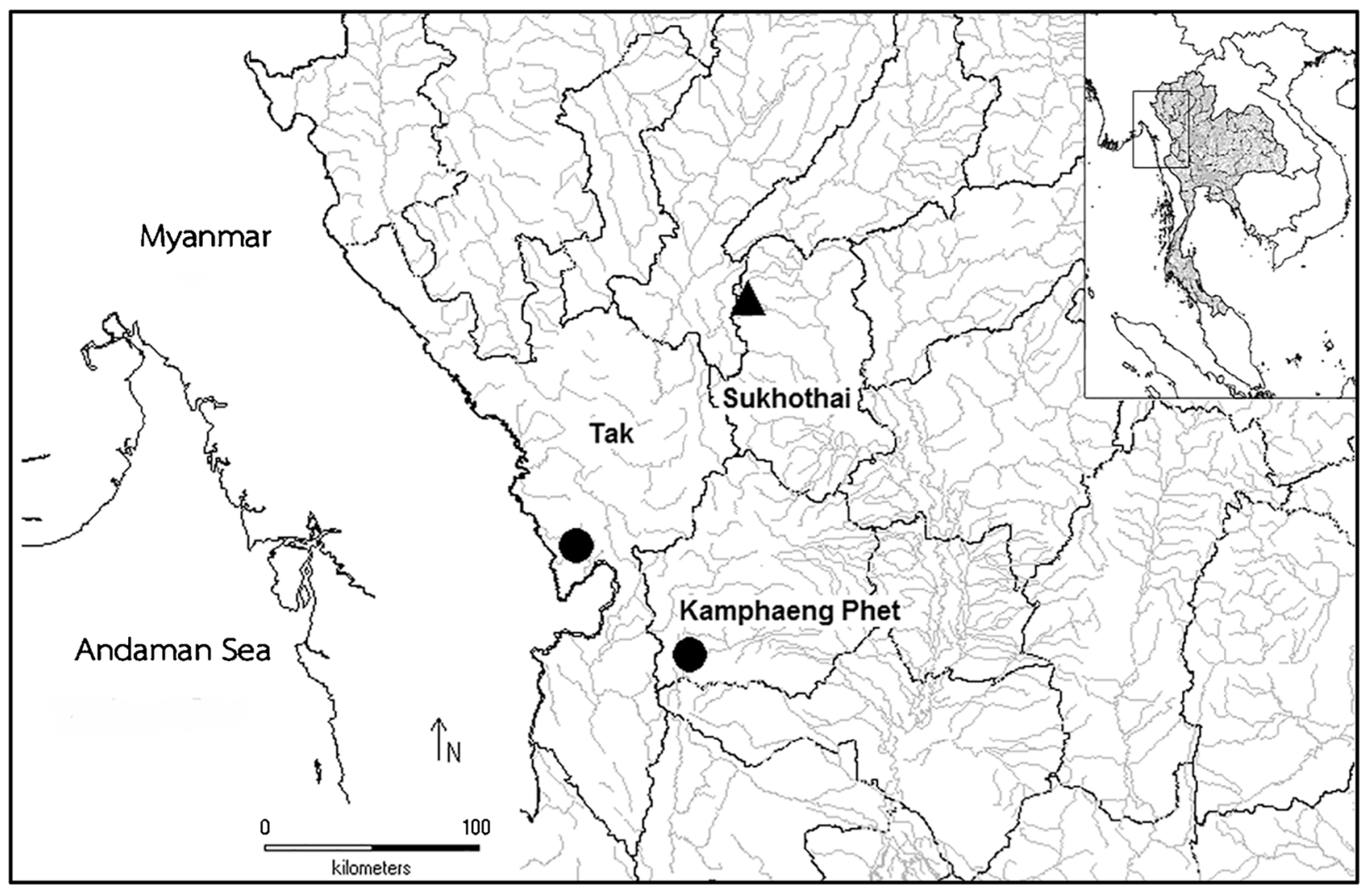

Map 1. Distribution of Justicia flavescens (closed triangle) and J. vasculosoides (closed circles) in northern Thailand. 

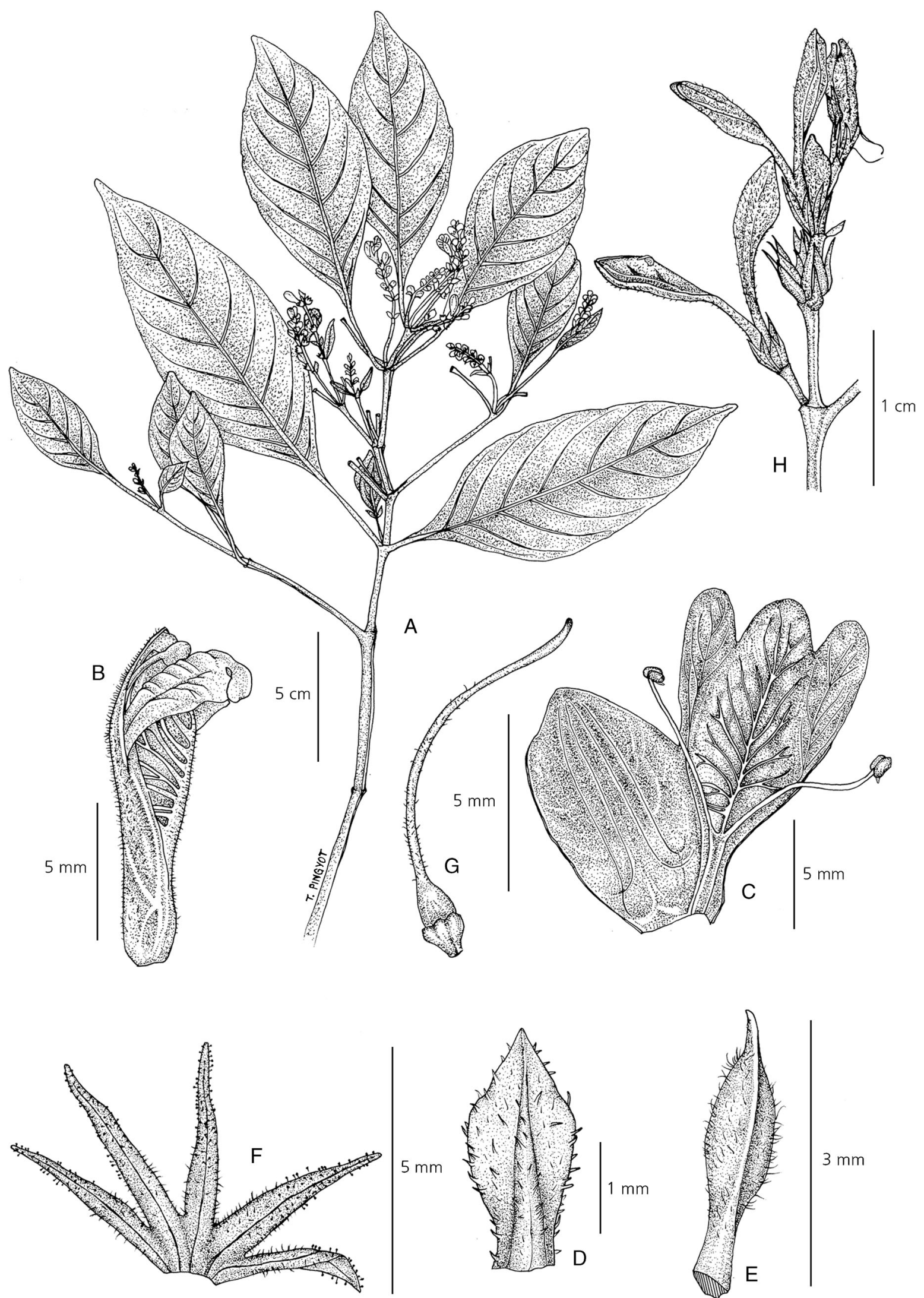

Fig. 3. Justicia vasculosoides A plant with inflorescences; B flower, lateral view; C dissected corolla, with stamens attached; D bract; E bracteole; F calyx; G pistil. All from the type. DRAWN BY T. PINGYOT. 


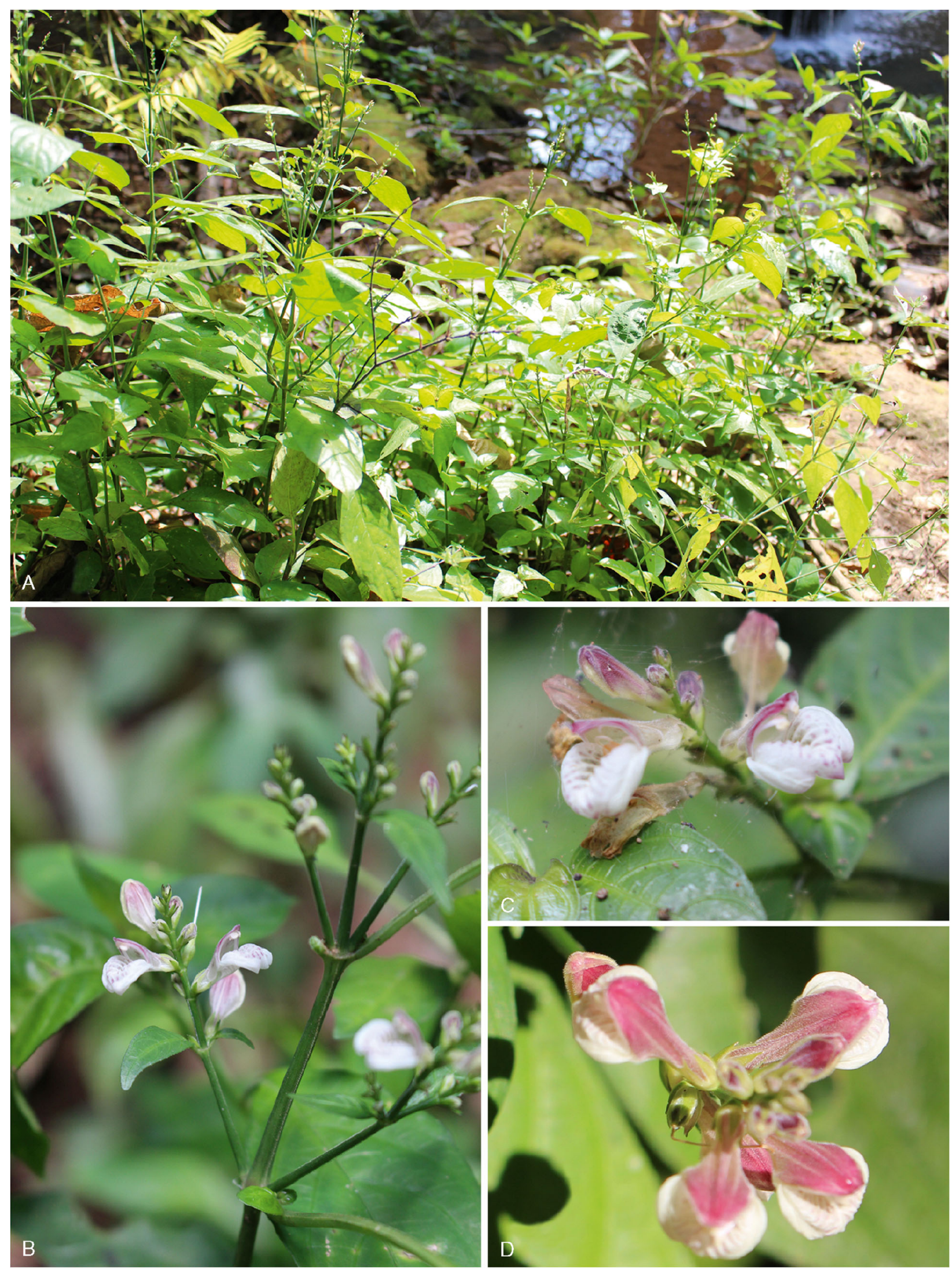

Fig. 4. Justicia vasculosoides A plant habit; B inflorescence; C flower showing lower corolla lip; D flower showing upper corolla lip. PHOTOS: K. RUEANGSAWANG. 
Table 2. Comparison of selected characters between Justicia vasculosoides and J. vasculosa.

\begin{tabular}{|c|c|c|}
\hline Character & J. vasculosoides & J. vasculosa \\
\hline \multicolumn{3}{|l|}{ Leaf } \\
\hline texture & chartaceous & thinly chartaceous \\
\hline shape & ovate or lanceolate to ovate & broadly ovate or elliptic \\
\hline apex & acuminate or caudate & acute or rounded \\
\hline base & attenuate & cuneate or obtuse \\
\hline size $(\mathrm{cm})$ & $6-14 \times 3-6$ & $8-18 \times 3.5-5.8$ \\
\hline \multicolumn{3}{|l|}{ Inflorescence } \\
\hline length $(\mathrm{cm})$ & $2-6$ & $7-19$ \\
\hline indumentum & glabrous to minutely pubescent & dense glandular hairs \\
\hline \multicolumn{3}{|l|}{ Bract } \\
\hline size $(\mathrm{mm})$ & $\begin{array}{l}3-7 \times 1-3 \\
\text { shorter than calyx }\end{array}$ & $\begin{array}{l}2-3.5 \times 1-1.4 \\
\text { as long as or a little shorter than the calyx }\end{array}$ \\
\hline indumentum & sparsely pubescent to glabrous & pubescent on both surfaces \\
\hline \multicolumn{3}{|c|}{ 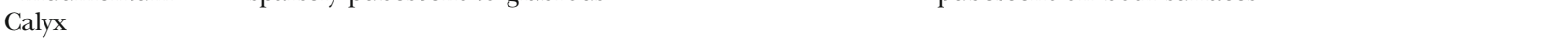 } \\
\hline size $(\mathrm{mm})$ & $3.7-5 \times 0.7-1$ & $2.5-3 \times 0.5-0.8$ \\
\hline \multicolumn{3}{|l|}{ Corolla } \\
\hline colour & $\begin{array}{l}\text { pink with pink or red markings on palate of lower lip, } \\
\text { tube cylindrical, pink }\end{array}$ & $\begin{array}{l}\text { creamy to white with pink markings on palate of lower } \\
\text { lip, tube cylindrical, white }\end{array}$ \\
\hline $\begin{array}{l}\text { middle lobe size } \\
(\mathrm{mm})\end{array}$ & $2-2.5 \times 2.5-2.8$ & $1-1.8 \times 1.8-2.2$ \\
\hline
\end{tabular}

1,340 m alt., 28 March 2015, K. Rueangsawang 305 (BKF!).

HABITAT. Open areas and along streams in evergreen forest; alt. 600 - 1340 m. Associated with Ageratina adenophora (Spreng.) R.M.King \& H.Rob. and Peristrophe lanceolaria (Roxb.) Nees.

CONSERVATION STATUS. A preliminary conservation assessment of Endangered [EN Blab(iii)+2ab(iii)] is appropriate. The extent of occurrence (EOO) is 60 $\mathrm{km}^{2}$ and the population occurs in disturbed and fragmented habitats due to human activity (mainly agriculture and urban development that have resulted in the extensive loss of forest cover). The area of occupancy (AOO) is less than $5 \mathrm{~km}^{2}$. Both collection localities are in protected areas.

PHENOLOGY. Flowering and fruiting between November - March.

ETYMOLOGY. The specific epithet "vasculosoides" refers to the new species' superficial resemblance to Justicia vasculosa.

NOTE. Justicia vasculosoides most likely belongs to sect. Tyloglossa (sensu Graham 1988) and, in common with J. vasculosa, has characteristics of this section, such as the spiciform inflorescence with one flower per node and linear to lanceolate bracts.

\section{Acknowledgements}

The authors are grateful to the curators and staff of AAU, BK, BKF, BM, C, CMU, E, K, KKU, L, P, QBG and SING for providing access to herbarium collections. Thanks also to Thitiporn Pingyot for the line drawings and Wattana Tanming for providing the photographs (Fig. 2). This research received support from the Rufford Small Grants Foundation (grant no RSG 17091 - 1).

Open Access This article is distributed under the terms of the Creative Commons Attribution 4.0 International License (http://creativecommons.org/ licenses/by/4.0/), which permits unrestricted use, distribution, and reproduction in any medium, provided you give appropriate credit to the original author(s) and the source, provide a link to the Creative Commons license, and indicate if changes were made.

\section{References}

Craib, W. G. (1912). Contributions to the Flora of Siam. Additamenta 2. Bull. Misc. Inform., Kew 1912: 264 - 269.

Bachman, S., Moat, J., Hill, A. W., de Torre, J. \& Scott, B. (2011). Supporting Red List threat assessments with GeoCAT: geospatial conservation assessment tool. ZooKeys 150: 117 - 126.

Forest Herbarium (2014). Thai Plant Names. Tem Smitinand. Revised Edition. The Forest Herbarium, Royal Forest Department, Bangkok.

Graham, V. A. W. (1988). Delimitation and infrageneric classification of Justicia (Acanthaceae). Kew Bull. 43: $551-624$.

Hansen, B. (1985). Studies on the Acanthaceae of Thailand. Fl. Males. Bull. 9: 173 - 178.

(1987). Justicia sect. Grossa sect. nov. (Acanthaceae). Nord. J. Bot. 7: 505 - 509.

(1989). Notes on SE Asian Acanthaceae 1. Nord. J. Bot. 9: $209-215$. 
Imlay, J. B. (1938). The Taxonomy of the Siamese Acanthaceae. Unpublished Ph.D. thesis, University of Aberdeen.

(1939). Contributions to the Flora of Siam Additamenta 51. Bull. Misc. Inform., Kew 1939: 109 - 150.

IUCN (2012). IUCN Red List Categories and Criteria, Version 3.1. Second edition. International Union for Conservation of Regional and Natural Resources, Gland and Cambridge.

Kiel, C. A., Daniel, T. F., Darbyshire, I. \& McDade, L. A. (2017). Unravelling relationships in the morphologically diverse and taxonomically challenging "justicioid" lineage (Acanthaceae: Justicieae). Taxon 66: 645 - 674 .

Mabberley, D. J. (2008). Mabberley's Plant-Book: A Portable Dictionary of Plants, their Classification and Uses, 3rd ed. Cambridge University Press, New York.
Ridley, H. N. (1922). On a collection of plants from Peninsular Siam. J. Fed. Malay. States Mus. 10: 105 - 110 .

Rueangsawang, K. (2012). Systematics of the Genus Justicia L. (Acanthaceae) in Thailand. Unpublished Ph.D. thesis, Khon Kaen University.

, Chantaranothai, P. \& Simpson, D. A. (2013). Pollen morphology of Justicia L. (Acanthaceae) from Thailand and its taxonomic value. Grana 52: $275-288$.

\section{Publisher's Note}

Springer Nature remains neutral with regard to jurisdictional claims in published maps and institutional affiliations. 